\title{
Surface Engineering
}

\section{Reclamation of thermal power plant waste as a distributed phase in electrodeposited $\mathrm{Ni}$ composite coating}

\section{S. T. Aruna, Abhilash Kiran \& M. Shilpa}

To cite this article: S. T. Aruna, Abhilash Kiran \& M. Shilpa (2019) Reclamation of thermal power plant waste as a distributed phase in electrodeposited Ni composite coating, Surface Engineering, 35:12, 1042-1047, DOI: $10.1080 / 02670844.2019 .1627487$

To link to this article: https://doi.org/10.1080/02670844.2019.1627487

曲 Published online: 16 Jun 2019.

Submit your article to this journal $₫$

Џ Article views: 13

Q View related articles $\square$

View Crossmark data ¿ 


\title{
Reclamation of thermal power plant waste as a distributed phase in electrodeposited Ni composite coating
}

\author{
S. T. Aruna, Abhilash Kiran and M. Shilpa
}

Surface Engineering Division, Council of Scientific and Industrial Research-National Aerospace Laboratories, Bangalore, India

ABSTRACT

In the exploration for newer and inexpensive distributed phases that can be used in electrodeposited $\mathrm{Ni}$-composite coatings, cenosphere particles which are one of the constituents of fly ash, the waste product of thermal power plants has been explored as a potential candidate material. An attempt was made to prepare electrodeposited Nicenosphere composite coating. The as-received cenosphere particles could be codeposited only after reducing the particle size by ball milling. The loading of cenosphere particles in the Ni-sulphamate bath was varied $\left(25,75\right.$ and $\left.100 \mathrm{~g} \mathrm{~L}^{-1}\right)$ and a maximum microhardness of $430 \mathrm{HK}$ at $50 \mathrm{gF}$ load was obtained for the coating deposited from $100 \mathrm{~g} \mathrm{~L}^{-1}$ cenosphere containing bath. The Ni-cenosphere composite coating with higher microhardness exhibited lower wear rate. Thus cenosphere, a waste product from thermal power plants is a potential candidate for a greener surface engineering strategy for improving the wear resistance of electrodeposited Ni composite coating.
ARTICLE HISTORY

Received 26 March 2019 Revised 29 April 2019

Accepted 25 May 2019

\section{KEYWORDS}

Electrodeposition; cenosphere; wear microhardness

\section{Introduction}

Electrodeposited metal matrix composites are in great demand for many advanced technological applications in various sectors like aerospace, defense, automobile, and nuclear power industries [1]. Such metal matrix coatings are being developed to meet the particular demands of low friction coefficient and high wear resistance [2]. The properties such as microhardness, corrosion and wear resistance of electrodeposited metals are further enhanced by incorporating inert particles such as oxides, non-oxides, fibres, microcapsules, etc. in the metal matrices [3] by codeposition. Electrodeposition is a cost-effective and attractive method as it is a low temperature and single step process which does not involve any additional thermal treatment [4]. Among the electrodeposited coatings, Ni-composite coatings are in great demand as alternative to electrodeposited $\mathrm{Cr}$ coatings. Ni metal matrix composites containing a large number of particles both in micrometre and nanosize have been reported. The particles such as $\mathrm{SiC}, \mathrm{ZrC}, \mathrm{TiO}_{2}, \mathrm{SiC}, \mathrm{CeO}_{2}, \mathrm{Al}_{2} \mathrm{O}_{3}, \mathrm{Si}_{3} \mathrm{~N}_{4}$, $\mathrm{WS}_{2}, \mathrm{CrAlY}$, WC, B, $\mathrm{B}_{4} \mathrm{C}, \mathrm{ZrO}_{2}$, zircon, pumice, carbon nanotubes (CNTs), diamond, etc. have been electrodeposited [5-14]. With growing concerns about environment, there is a need to evolve new strategies in the reclamation of industrial waste. The present work was aimed at using waste material with a goal to develop value-added coating. An attempt has been made in this work to use cenospheres, a waste product from coal thermal power plants as the distributed phase in the electrodeposited nickel metal matrix composite coating.

Coal power plants produce waste material consisting of the non-combustible mineral portion of coal which solidifies as microscopic glassy particles that are collected from the exhaust of power plant's before they fly away and are termed as fly ash particles. Fly ash also contains grey coloured, lighter (density-0.4$0.8 \mathrm{~g} \mathrm{~cm}^{-3}$ ) glassy hollow microspheres termed as cenospheres [15-18]. Normally, cenospheres have a high silica and mullite $\left(3 \mathrm{Al}_{2} \mathrm{O}_{3} \cdot 2 \mathrm{SiO}_{2}\right)$ content and are used in cementitious and concrete products [1620]. They are notably used as fillers as they are lighter, harder and rigid, waterproof, insulating, etc. Silvercoated cenospheres are used in conductive paints for antistatic coatings and electromagnetic shielding [21].

There are no reports on the synthesis and properties of electrodeposited Ni composite coatings containing cenosphere particles. In the present study, the synthesis and properties of electrodeposited Ni-cenosphere composite coatings is reported.

\section{Experimental}

Cenosphere powder was received from Central Power Research Institute (CPRI), Bangalore, India and was characterised by powder X-ray diffractometry (XRD, Bruker D-8), particle size analysis (MasterSizer 2000) and field emission scanning electron microscopy (FESEM, Carl Zeiss). The particle size distribution of 
as received and ball milled cenosphere powder was determined using particle size analyser based on laser diffraction (Malvern, Mastersizer 2000). Ni-cenosphere coatings were electrodeposited from a Ni-sulphamate bath containing cenosphere particles $(25,75$ and $100 \mathrm{~g} \mathrm{~L}^{-1}$ ) on brass substrate and brass pin substrates for microhardness and wear studies respectively. Before electrodeposition the substrates were cleaned as follows: the substrate was washed with a suitable detergent and degreased with acetone; then cathodically cleaned in $20 \% \mathrm{NaOH}$ at $0.0645 \mathrm{~A} \mathrm{dm}^{-2}$ and followed by acid dipping in $10 \% \mathrm{H}_{2} \mathrm{SO}_{4}$. About $200 \mathrm{~mL}$ of the Ni-sulphamate solution ( $\mathrm{pH}$ maintained at 4 ) containing nickel chloride, boric acid, sodium lauryl sulphate $\left(0.2 \mathrm{~g} \mathrm{~L}^{-1}\right)$ was used as the electrolyte. The brass substrate was used as cathode and a nickel substrate with the same dimension was used as anode. Details regarding the bath composition, electrodeposition parameters are reported elsewhere [22]. There was very less co-deposition of cenosphere particles with $\mathrm{Ni}$ when the as-received powder was used as the distributed phase. So the as-received cenosphere particles were ball-milled for $3 \mathrm{~h}$ in ethanol medium, dried and dispersed in a nickel sulphamate bath $(25,75$ and $100 \mathrm{~g} \mathrm{~L}^{-1}$ ) and stirred well for $16 \mathrm{~h}$ before electrodeposition. Then electrodeposition was carried out at different current densities $\left(0.75,1.54\right.$ and $\left.3.1 \mathrm{~A} \mathrm{dm}^{-2}\right)$ and for different durations so that $\sim 50 \mu \mathrm{m}$ coating thickness was obtained and the optimised current density was $0.75 \mathrm{~A} \mathrm{dm}^{-2}$.

Brass substrates containing electrodeposited $\mathrm{Ni}$ cenosphere coatings were given a $\mathrm{Cu}$ back up layer, cut into desired size and moulded in a Bakelite matrix followed by metallographic grinding and polishing and were used for cross-sectional analysis using optical microscope (Leica DM-1RM). The microhardness of the as prepared Ni coating was tested in a microhardness tester using Knoop indenter on ten different locations on the cross-section of each coating (Micromet 2103, Buehler, $50 \mathrm{gf}$ load). The surface roughness profile of $\mathrm{Ni}$ coating was measured by profilometer (Taylor Hobson). Wear studies were carried out using the coated brass pins on a pin-on-disc tribometer (DUCOM) and detailed testing procedures are documented in literature [22]. FESEM was used to study the microstructure of the coatings. Energy dispersive $\mathrm{X}$-ray spectroscopy (EDS, Oxford instrument's Inca Penta FET X3 model) integrated with FESEM instrument was used for elemental analysis of the powder and electrodeposited $\mathrm{Ni}$ composite coatings.

\section{Results and discussion}

\section{Cenosphere powder characterisation}

Optical micrograph of as received fly-ash cenosphere particles is presented in Figure 1. The as-received cenosphere particles have spherical morphology and the EDX analysis showed the presence of $\mathrm{SiO}_{2}, \mathrm{Al}_{2} \mathrm{O}_{3}$ and $\mathrm{Fe}_{2} \mathrm{O}_{3}$. The FESEM images of ball milled cenosphere particles are shown in Figure 1(b). The ball-milled particles are irregular in shape unlike the spherical nature of the cenosphere.

The XRD analysis of cenosphere particles showed the presence of different phases like mullite, quartz, cristobalite, haematite, sodium titanium oxide as shown in Figure 2.

The EDAX analysis of the powder revealed the presence of $\mathrm{Na}$ (1.04 wt-\%), $\mathrm{Mg}$ (0.35 wt-\%), $\mathrm{Al}$ (12.72 wt$\%)$, Si (17.44 wt-\%), Fe (29.05 wt-\%), K (0.49 wt-\%),

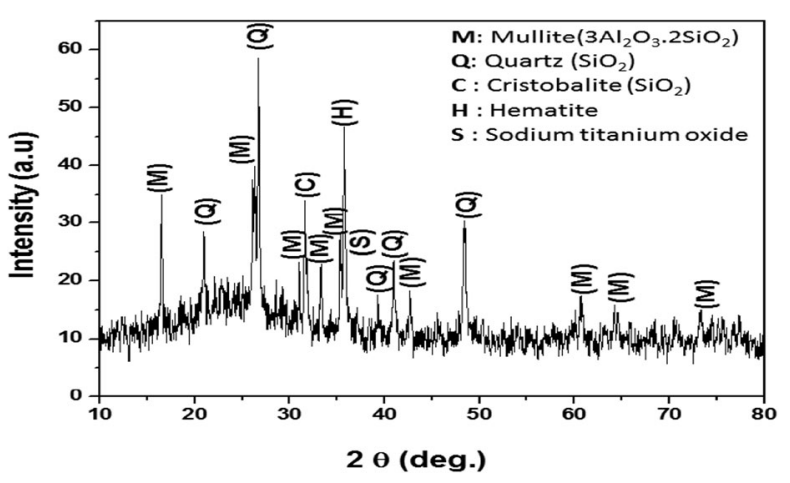

Figure 2. Powder XRD pattern of ball milled cenosphere powder.
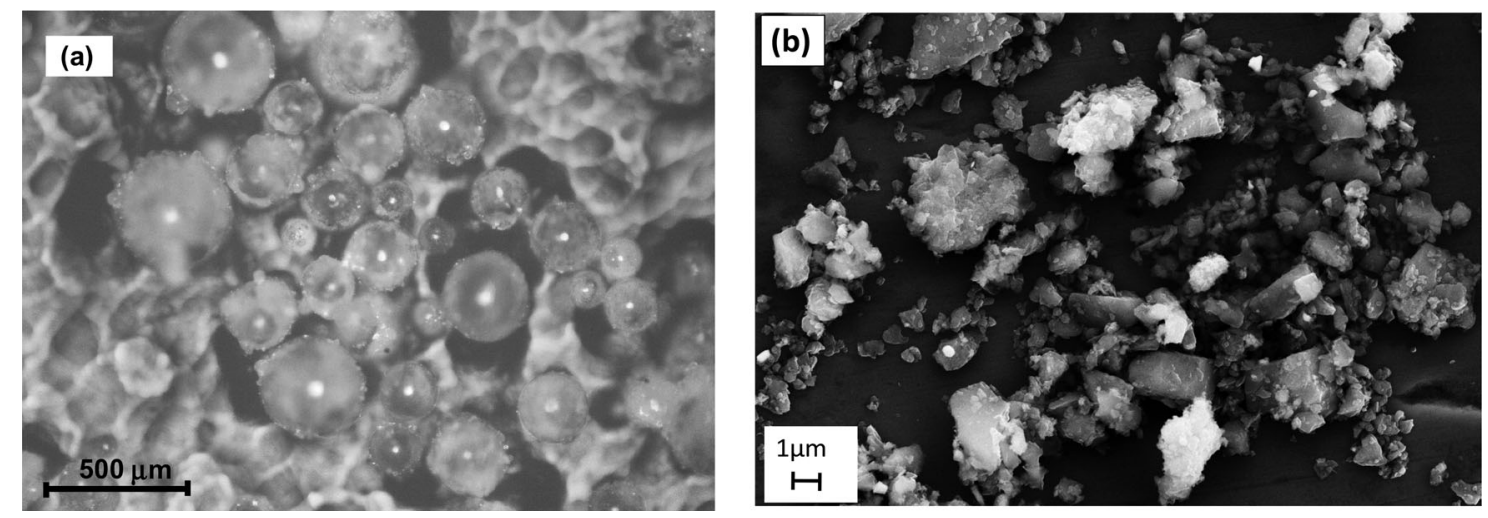

Figure 1. (a) Optical micrograph of (a) as-received cenosphere powder and (b) FESEM image of ball milled cenosphere powder. 
Ca (0.49 wt-\%), Ti (0.63 wt-\%) and O (37.80 wt-\%). The average agglomerated particle size of cenosphere particles reduced from 33.93 to $2.33 \mu \mathrm{m}$ upon ball milling.

\section{Characterisation of the coatings}

The cross-sectional optical micrographs of Ni-cenosphere composite coatings obtained at $0.75 \mathrm{~A} \mathrm{dm}^{-2}$ with various particle loadings in the bath are shown in Figure 3. From Figure 3 it is evident that with increasing particle loading the \% of particles incorporated in the Ni matrix increases and thus the optimised particle loading was $100 \mathrm{~g} \mathrm{~L}^{-1}$. Upon further increasing the particle loading there was no drastic increase in the particle \% incorporation.

Generally, the electrodeposited $\mathrm{Ni}$ coating exhibits irregular features (Figure 4(a)) [23]. With the incorporation of cenosphere particles, nodular feature became more prominent and cauliflower like structures are observed which indirectly indicates the influence of
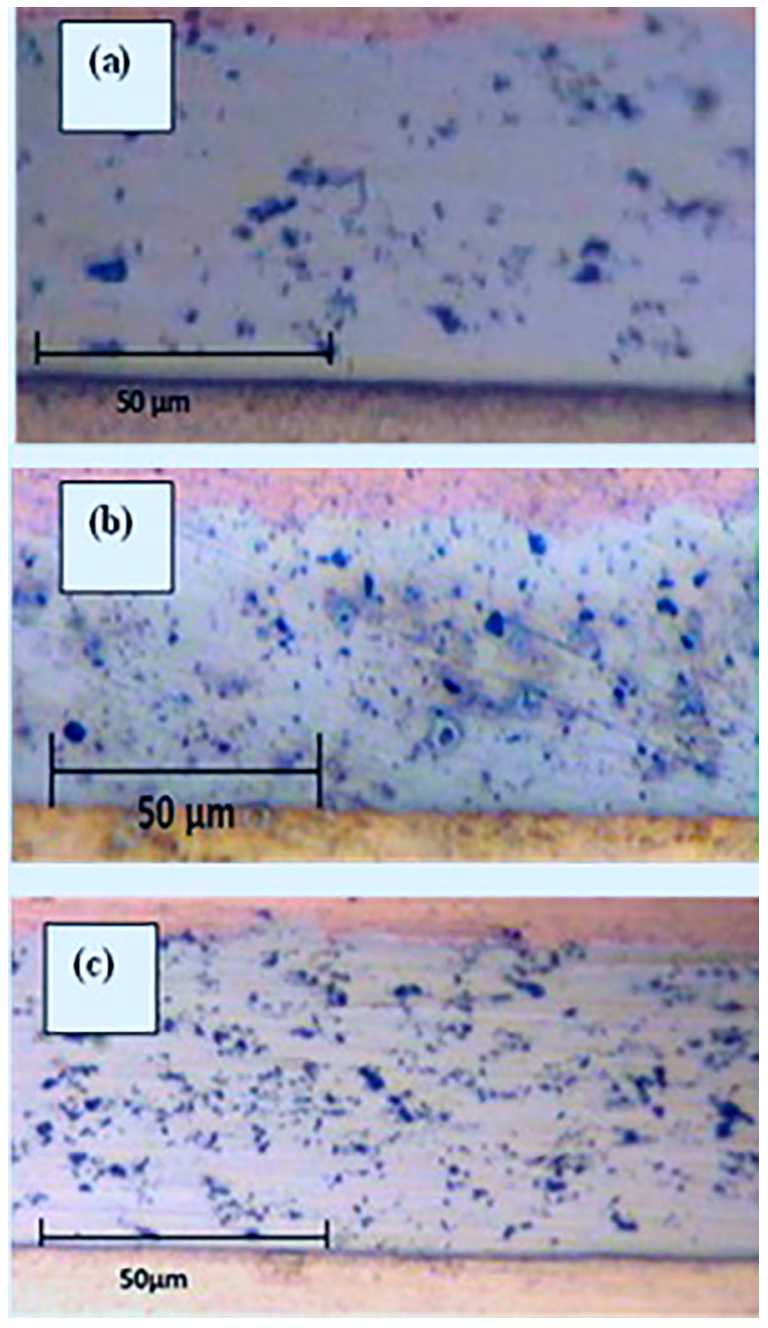

Figure 3. Cross-sectional optical micrographs of $\mathrm{Ni}$-cenosphere composite coatings obtained at $0.75 \mathrm{~A} \mathrm{dm}^{-2}$ with various particle loadings in the bath (a) $25 \mathrm{~g} \mathrm{~L}^{-1}$, (b) $75 \mathrm{~g} \mathrm{~L}^{-1}$ and (c) $100 \mathrm{~g} \mathrm{~L}^{-1}$. the codeposited particles on the morphology of the coating (Figure 4(b and c)). The EDX analysis on the black spot in Figure 4(c) conforms to cenosphere particles. Figure 5 shows the EDX spectra of the coating and it confirms the presence of more of $\mathrm{Ni}$ (77.30 wt$\%)$ and the rest corresponding to elements such as $\mathrm{Na}, \mathrm{Al}, \mathrm{Si}, \mathrm{Fe}, \mathrm{O}, \mathrm{Cl}, \mathrm{C}$ and Co corresponding to cenosphere composition (inset in Figure 5).

There was no change in the orientation of XRD peaks corresponding to $\mathrm{Ni}$ on incorporation of cenosphere particles and (200) was the major peak in both $\mathrm{Ni}$ and $\mathrm{Ni}$-cenosphere coatings. This indicates preferred orientation of (200) plane parallel to coating surface. However, there was a drastic reduction in the intensity of (220) peak and a slight reduction in the intensity of (111) peak in Ni-cenosphere coating. This indicates that plain $\mathrm{Ni}$ and $\mathrm{Ni}$-cenosphere coatings have different population of each crystal plane. Also, there was not much change in the crystallite
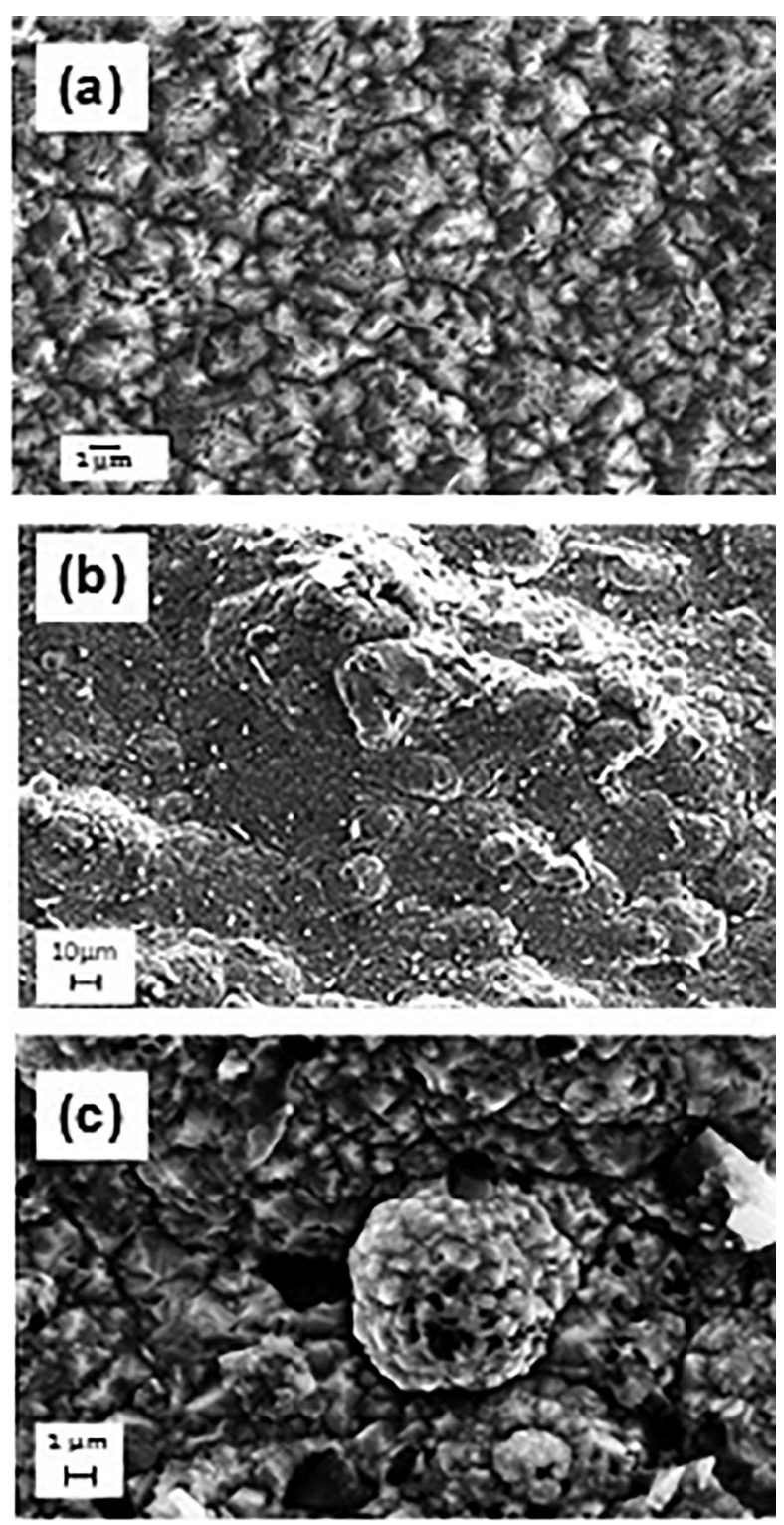

Figure 4. FESEM images of the surface of $\mathrm{Ni}$ (a) and Ni-cenosphere $\left(100 \mathrm{~g} \mathrm{~L}^{-1}\right)$ coating at different magnifications (b, c). 


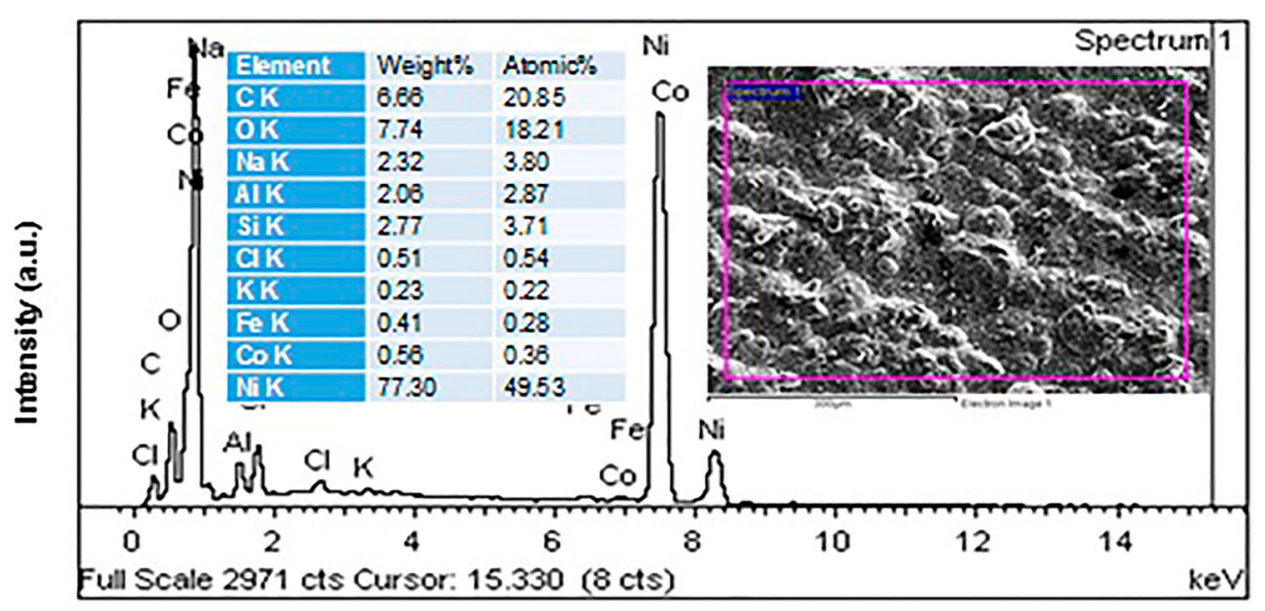

Figure 5. EDX spectra of the Ni-cenosphere coating and in-set shows the presence of main element Ni apart from the presence of elements present in cenosphere.

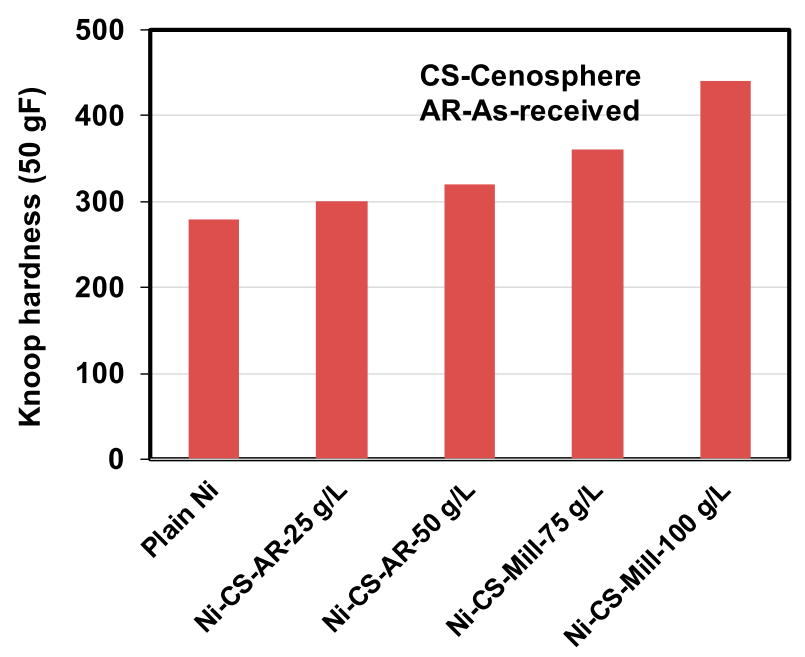

Figure 6. Histograms showing the hardness of $\mathrm{Ni}$ and $\mathrm{Ni}$-cenosphere composite coatings.

size of Ni on incorporation of cenosphere particles. No peaks corresponding to cenosphere particles were observed which may be attributed to the less $\%$ of particle incorporation. The surface roughness of Ni coating was $0.1794 \mu \mathrm{m}$ and that of Ni-cenosphere coating $\left(100 \mathrm{~g} \mathrm{~L}^{-1}\right)$ was $2.1 \mu \mathrm{m}$ which is also evident from the nodular microstructure of $\mathrm{Ni}$-cenosphere coating.

The microhardness of the as prepared Ni coating was $280 \mathrm{HK}$ at an applied load of $50 \mathrm{gF}$ (gram Force) and that of Ni-cenosphere coating $\left(100 \mathrm{~g} \mathrm{~L}^{-1}\right)$ was $\sim 430 \mathrm{HK}$. The microhardness of $\mathrm{Ni}$-cenosphere coatings increased with increasing particle loading in the bath (Figure 6). The incorporated particles act as barriers and inhibit easy dislocation movements and thus in turn increase the microhardness of the nickel composite coating according to Orowan mechanism [24].

The wear data of $\mathrm{Ni}$ and $\mathrm{Ni}$-cenosphere coatings are shown in Table 1. From the table, it is evident that Ni-cenosphere coatings exhibit lower wear volume loss and lower wear rate compared to plain
Table 1. Wear data of $\mathrm{Ni}$ and Ni-cenosphere coatings.

\begin{tabular}{lcccc}
\hline Sample & $\begin{array}{c}\text { Coefficient of } \\
\text { friction }\end{array}$ & $\begin{array}{c}\text { Wear } \\
\text { volume } \\
\left(\mathrm{mm}^{3}\right)\end{array}$ & $\begin{array}{c}\text { Wear } \\
\text { coefficient }\end{array}$ & $\begin{array}{c}\text { Wear rate } \\
\left(\mathrm{mm}^{3} \mathrm{Nm}^{-1}\right)\end{array}$ \\
\hline Plain Ni & 0.67 & 0.29 & $2.6 \times 10^{-4}$ & $2.02 \times 10^{-4}$ \\
$25 \mathrm{~g} \mathrm{~L}^{-1}$ & 0.75 & 0.14 & $1.2 \times 10^{-4}$ & $9.7 \times 10^{-5}$ \\
$75 \mathrm{~g} \mathrm{~L}^{-1}$ & 0.75 & 0.06 & $2.5 \times 10^{-5}$ & $4.18 \times 10^{-5}$ \\
$100 \mathrm{~g} \mathrm{~L}^{-1}$ & 0.75 & 0.05 & $4.8 \times 10^{-5}$ & $3.49 \times 10^{-5}$ \\
\hline
\end{tabular}

$\mathrm{Ni}$. Ni-cenosphere coating obtained at $100 \mathrm{~g} \mathrm{~L}^{-1}$ exhibited lower wear loss when compared to other coatings. However, the coefficient of friction was slightly higher for the $\mathrm{Ni}$-cenosphere coatings compared to plain nickel. This may be attributed to the abrasive nature of the incorporated particles. It is well documented in the literature that the wear resistance and hardness of composite coatings are related to each other as well as to the particle content of the deposits. It is gratifying to note that the obtained wear rate is in the same order as that of $\mathrm{Ni}-\mathrm{SiC}$ coating deposited and measured under identical conditions (wear rate of $\mathrm{Ni}-\mathrm{SiC}-1.35 \times 10^{-5} \mathrm{~mm}^{3} \mathrm{Nm}^{-1}$ and COF-0.75). Electrodeposited $\mathrm{Ni-SiC}$ is being commercially used in coating of trochoid of Wankel engine and automobile rotary engines.

Figure $7(\mathrm{a}$ and $\mathrm{b})$ shows the optical images of the disc after wear testing corresponding to the transfer of $\mathrm{Ni}$ and Ni-cenosphere composite coating on to the disc $\left(100 \mathrm{~g} \mathrm{~L}^{-1}\right)$. The wear coefficient for plain $\mathrm{Ni}$ and Ni-cenosphere coatings are in the range of $10^{-4}$ to $10^{-5}$ which refers to moderate adhesive wear [25]. The wear mechanism of both the coating surface is mainly adhesive in nature and the friction pairs generate plowing marks on the disc surface as seen from the optical images (Figure 7). However, wear debris is observed in case of Ni-cenosphere coating transferred disc which may correspond to the cenosphere particles. No deep scratches were observed thus ruling out abrasive wear in Ni-cenosphere coating. 


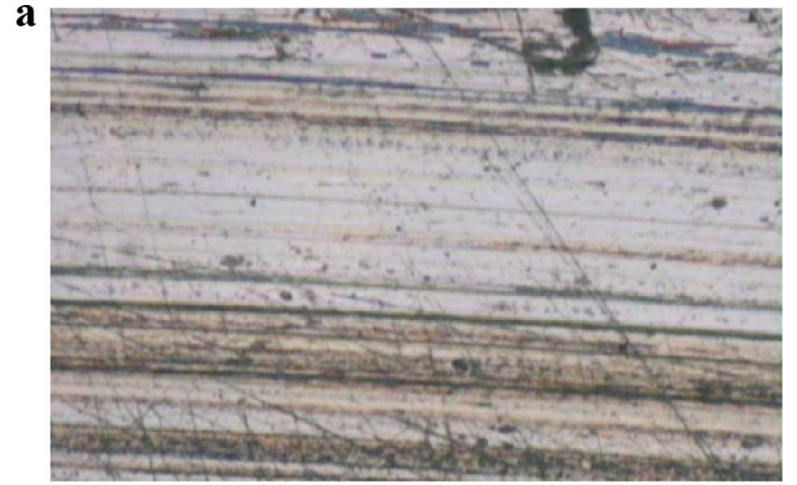

b

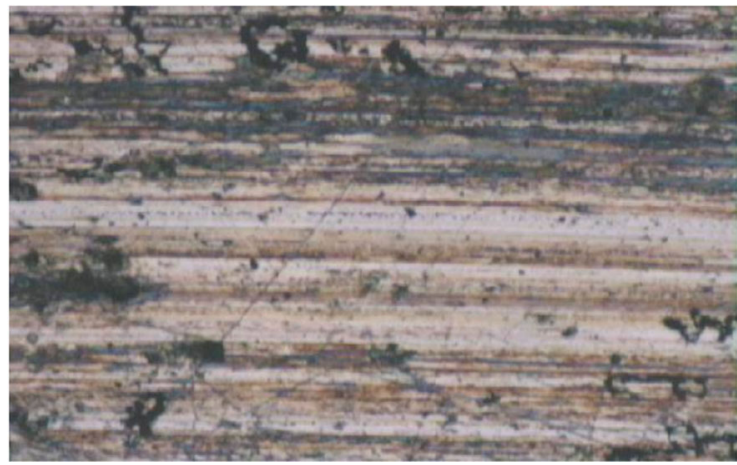

Figure 7. (a) Optical image of Ni transferred disc. (b) Optical image of Ni-cenosphere transferred disc.

\section{Conclusions}

- In the present work, reclamation of waste material from thermal power plant was carried out with the aim of developing a cost-effective wear resistant electrodeposited composite coating.

- Cenosphere, a fly ash waste product was explored as the distributed phase in the electrodeposited $\mathrm{Ni}$ composite coating.

- Only after reducing the particle size of cenosphere powder $(40-3.2 \mu \mathrm{m})$ more particles could be incorporated in the $\mathrm{Ni}$ matrix without the aid of any surfactant.

- The $\%$ of incorporated particles increased with increasing bath loading. The coating deposited with $100 \mathrm{~g} \mathrm{~L}^{-1}$ powder loaded bath exhibited higher microhardness $(430 \mathrm{HK})$ compared to plain $\mathrm{Ni}$ (280 HK).

- Electrodeposited Ni-cenosphere coatings showed improved wear resistant properties compared to plain $\mathrm{Ni}$ and equivalent to $\mathrm{Ni}$-SiC.

- The work demonstrated a novel application of thermal power plant waste and is a green surface engineering strategy.

\section{Acknowledgements}

The authors thank Director, NAL and Head, SED for his constant encouragement. The authors thank Dr Shekar Kumar of CPRI, Bangalore for providing the cenospheres.
The authors also thank Mr Muni Prakash, Mr N. Balaji and $\mathrm{Mr}$ Siju for the help received in wear studies, particle size analysis and FESEM studies respectively.

\section{Disclosure statement}

No potential conflict of interest was reported by the authors.

\section{References}

[1] Garcia I, Fransaer J, Celis J-P. Electrodeposition and sliding wear resistance of nickel composite coatings containing micron and submicron $\mathrm{SiC}$ particles. Surf Coat Technol. 2001;148:171-178.

[2] Xiao CJ. Properties of nano-SiC/Ni composite coating on diamond surfaces. Surf Eng. 2018;34(11):832-837.

[3] Zhang Z, Wu X, Jiang C, et al. Electrodeposition of Ni matrix composite coatings containing $\mathrm{ZrC}$ particles. Surf Eng. 2014;30:21-25.

[4] Liu S, Bian X, Liu J, et al. Structure and properties of $\mathrm{Ni}-\mathrm{P}$-graphite $\left(\mathrm{C}_{\mathrm{g}}\right)-\mathrm{TiO}_{2}$ composite coating. Surf Eng. 2015;31:420-426.

[5] Kucharska B, Popławski K, Jezierska E, et al. Influence of stirring conditions on $\mathrm{Ni} / \mathrm{Al}_{2} \mathrm{O}_{3}$ nanocomposite coatings. Surf Eng. 2016;32:457-463.

[6] Jiang JB, Zhang L, Zhong QD, et al. Preparation and characterisation of nickel-nano- $\mathrm{B}_{4} \mathrm{C}$ composite coatings. Surf Eng. 2012;28:612-619.

[7] Bates BL, Zhang LZ, Zhang Y. Electrodeposition of Ni matrix composite coatings with embedded CrAlY particles. Surf Eng. 2015;31:202-208.

[8] Gupta RN, Das AK, Nagahanumaiah, et al. Pulse electrocodeposited Ni-WC composite coating. Mater Manuf Process. 2016;31:42-47.

[9] Aruna ST, Arunima S, Latha S, et al. Preparation of oilencapsulated microcapsules and tribological property of Ni composite coating. Mater Manuf Process. 2016;31:107-111.

[10] Roy D, Das AK, Saini R, et al. Pulse current co-deposition of Ni-WS $\mathrm{W}_{2}$ nano-composite film for solid lubrication. Mater Manuf Process. 2017;32:365-372.

[11] Omidvar H, Sajjadnejad M, Stremsdoerfer G, et al. Composite NiB-graphite and NiB-PTFE surface coatings deposited by the dynamic chemical plating technique. Mater Manuf Process. 2016;31:24-30.

[12] Staia MH, Conzoño A, Cruz MR, et al. Wear behaviour of silicon carbide/electroless nickel composite coatings at high temperature. Surf Eng. 2002;18:265-269.

[13] Borkar T, Harimkar S. Microstructure and wear behaviour of pulse electrodeposited Ni-CNT composite coatings. Surf Eng. 2011;27:524-530.

[14] Parucker ML, Klein AN, Binder R. Influence of phosphorus on the development of nickel alloy/h-BNbased self-lubricating composites processed by powder metallurgy. Comp Interf. 2015;22(2):85-94.

[15] Chávez-Valdez A, Arizmendi-Morquecho A, Vargas $\mathrm{G}$, et al. Ultra-low thermal conductivity thermal barrier coatings from recycled fly-ash cenospheres. Acta Mater. 2011;59:2556-2562.

[16] Sear LKA. The properties and use of coal fly ash. London: Thomas Telford Publishing; 2001.

[17] Jung JS, Park HC, Stevens R. Mullite ceramics derived from coal fly ash. J Mater Sci Lett. 2001;20:1089-1091.

[18] Berry EE, Malhotra VM. Fly ash for use in concrete-a critical review. J Amer Concrete Ins. 1990;77:59-73. 
[19] Laneand RO, Best JF. Properties and use of fly ash in Portland cement concrete. Concr Int. 1982;4:81-92.

[20] Halse Y, Pratt PL. Development of microstructure and other properties in flyash OPC systems. Cement Concrete Res. 1984;14:491-498.

[21] https://en.wikipedia.org/wiki/Cenosphere accessed on 19th March 2019.

[22] Aruna ST, Srinivas G. Wear and corrosion resistant properties of electrodeposited $\mathrm{Ni}$ composite coating containing $\mathrm{Al}_{2} \mathrm{O}_{3}-\mathrm{TiO}_{2}$ composite powder. Surf Eng. 2015;31:708-713.

[23] Aruna ST, Savitha G, Shedthi J, et al. The Corrosion Resistance of Nickel Electrocomposite Coating Containing BaFe12O19 Particles. ISRN Corrosion. 2013; doi:10.1155/2013/192684

[24] Dieter GE. Mechanical metallurgy. 3rd ed. New York: McGraw-Hill; 1986.

[25] Rabinowicz E. The least wear. Wear. 1984;100:533-541. 